\title{
Mesonia mobilis sp. nov., isolated from seawater, and emended description of the genus Mesonia
}

\author{
Correspondence \\ Olga I. Nedashkovskaya \\ olganedashkovska@piboc.dvo.ru \\ or \\ olganedashkovska@yahoo.com
}

\author{
Olga I. Nedashkovskaya, ${ }^{1}$ Seung Bum Kim, ${ }^{2}$ Natalia V. Zhukova, ${ }^{3}$ \\ Jangryul Kwak, ${ }^{4}$ Valery V. Mikhailov' ${ }^{1}$ and Kyung Sook Bae ${ }^{4}$ \\ ${ }^{1}$ Pacific Institute of Bioorganic Chemistry of the Far-Eastern Branch of the Russian Academy
of Sciences, Pr. 100 Let Vladivostoku 159, 690022, Vladivostok, Russia \\ ${ }^{2}$ Department of Microbiology, School of Bioscience and Biotechnology, Chungnam National \\ University, 220 Gung-dong, Yusong, Daejon 305-764, Republic of Korea \\ ${ }^{3}$ Institute of Marine Biology of the Far-Eastern Branch of the Russian Academy of Sciences, \\ Pal'chevskogo St 17, 690032, Vladivostok, Russia \\ ${ }^{4}$ Korea Research Institute of Bioscience and Biotechnology, 52 Oun-dong, Yusong, Daejon \\ 305-333, Republic of Korea
}

The taxonomic position of a novel marine, heterotrophic, strictly aerobic, gliding and yellow-

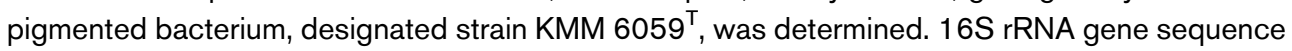
analysis revealed that this strain represents a member of the genus Mesonia. Phenotypic and chemotaxonomic data showed that the isolate represents a novel species of the genus Mesonia, for which the name Mesonia mobilis sp. nov. is proposed. The type strain is $\mathrm{KMM} 6059^{\top}(=\mathrm{KCTC}$ $12708^{\top}=$ LMG $23670^{\top}$ ). An emended description of the genus Mesonia based on the new data is also given.
The genus Mesonia, comprising the single species Mesonia algae (Nedashkovskaya et al., 2003), was erected to accommodate Gram-negative, strictly aerobic, heterotrophic, yellow-pigmented and non-motile marine bacteria belonging to the family Flavobacteriaceae (Bernardet et al., 2002). Strains of $M$. algae were isolated from the common Pacific green alga Acrosiphonia sonderi. The genus Mesonia forms a phylogenetic cluster with the genera Salegentibacter and Gramella.

During June 2000 we isolated an unknown bacterial strain, designated KMM $6059^{\mathrm{T}}$, from a seawater sample collected in Troitsa Bay, Gulf of Peter the Great, Sea of Japan. A polyphasic taxonomic study of this strain indicated that it represents a novel species of the genus Mesonia.

Genomic DNA extraction, PCR and sequencing of the $16 \mathrm{~S}$ rRNA gene followed the procedures given in Kim et al. (1998). To establish the precise taxonomic position of strain KMM $6059^{\mathrm{T}}, 1434 \mathrm{nt}$ of its $16 \mathrm{~S}$ rRNA gene sequence was determined, $1405 \mathrm{bp}$ of which were used for comparative phylogenetic analysis. The sequence data obtained were aligned with sequences of representative members of the family Flavobacteriaceae retrieved from EMBL using PHYDIT version 3.2 (http://plaza.snu.ac.kr/ jchun/phydit/).

\footnotetext{
Abbreviation: FAME, fatty acid methyl ester.
}

The GenBank/EMBL/DDBJ accession number for the 16S rRNA gene sequence of Mesonia mobilis KMM 6059 ${ }^{\top}$ is DQ367409.
Phylogenetic trees were inferred using suitable programs of the PHYLIP package (Felsenstein, 1993). Phylogenetic distances were calculated from Kimura's two-parameter model (Kimura, 1980), and trees were constructed on the basis of the neighbour-joining (Saitou \& Nei, 1987), leastsquares (Fitch \& Margoliash, 1967) and maximum-likelihood (Felsenstein, 1993) algorithms. Bootstrap analysis was performed with 1000 resampled datasets, using the SEQBOOT and CONSENSE programs of the PHYLIP package.

$16 \mathrm{~S}$ rRNA gene sequence analysis indicated that strain KMM $6059^{\mathrm{T}}$ was a member of the family Flavobacteriaceae and formed a distinct branch within the genus Mesonia (Fig. 1). The level of $16 \mathrm{~S}$ rRNA gene sequence similarity between $\mathrm{KMM} 6059^{\mathrm{T}}$ and M. algae $\mathrm{KMM} 3909^{\mathrm{T}}$ was $95 \cdot 8 \%$.

Genomic DNA was isolated according to the method of Marmur (1961) and the G+C content of the DNA was determined by the thermal denaturation method (Marmur \& Doty, 1962). The DNA base composition of KMM $6059^{\mathrm{T}}$ was $36 \cdot 1 \mathrm{~mol} \% \mathrm{G}+\mathrm{C}$.

In order to determine whole-cell fatty acid and polar lipid profiles, strains KMM $6059^{\mathrm{T}}$ and M. algae KMM $3909^{\mathrm{T}}$ were grown at $28^{\circ} \mathrm{C}$ for $48 \mathrm{~h}$ on marine agar 2216 (Difco). Lipids were extracted by a method modified from that of Bligh \& Dyer (1959). Polar lipids were separated by two-dimensional micro-TLC in solvent systems as described by Vaskovsky \& Terekhova (1979). Lipids were detected by TLC using $10 \% \mathrm{H}_{2} \mathrm{SO}_{4}$ in methanol with subsequent 


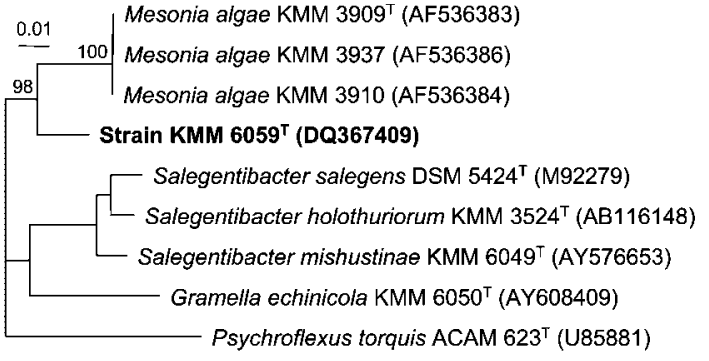

Fig. 1. Neighbour-joining tree based on 16S rRNA gene sequences of $\mathrm{KMM} 6059^{\top}$ and members of related genera of the family Flavobacteriaceae. The topology was not changed in trees constructed with the least-squares or maximum-likelihood methods. Numbers at nodes are bootstrap values (percentages of 1000 resampled datasets). Bar, 0.01 substitutions per nucleotide position.

heating to $180^{\circ} \mathrm{C}$, and using specific reagents for phospholipids (Vaskovsky et al., 1975) and amino group-containing lipids ( $2 \%$ ninhydrin in acetone). The lipids were treated with $5 \% \mathrm{HCl}$ in methanol at $80^{\circ} \mathrm{C}$ for $180 \mathrm{~min}$ to produce fatty acid methyl esters (FAMEs) (Christie, 1982). FAMEs were analysed in a flame ionization detector gas chromatograph (Shimadzu GC-17) with a fused silica capillary column $(30 \mathrm{~m} \times 0.25 \mathrm{~mm})$ coated with Supelcowax 10 at $210^{\circ} \mathrm{C}$. Helium was used as carrier gas. FAMEs were identified by comparing the retention times with those of authentic standards and using equivalent chain length measurements. To ensure correct identification, FAMEs were also analysed by GC-MS (Shimadzu QP5050A) with an MDN-5S capillary column $(30 \mathrm{~m} \times 0.25 \mathrm{~mm})$. The column temperature was programmed as follows: $1 \mathrm{~min}$ hold at $170^{\circ} \mathrm{C}$, followed by an increase to $240^{\circ} \mathrm{C}$ at $2{ }^{\circ} \mathrm{C} \mathrm{min}^{-1}$, and a hold at $240^{\circ} \mathrm{C}$ for $20 \mathrm{~min}$. The temperature of the injector and detector was $250^{\circ} \mathrm{C}$.

Phosphatidylethanolamine was the only phospholipid identified. The predominant cellular fatty acids of KMM $6059^{\mathrm{T}}$ and M. algae KMM $3909^{\mathrm{T}}$ were straight-chain unsaturated, branched-chain unsaturated and saturated, namely iso- $\mathrm{C}_{15: 0}$, anteiso- $\mathrm{C}_{15: 0}, \mathrm{C}_{15: 0}$, iso- $\mathrm{C}_{15: 1}, \mathrm{C}_{16: 1} \omega 7$, iso- $\mathrm{C}_{17: 1}$ and iso- $\mathrm{C}_{15: 0} 2-\mathrm{OH}$ (Table 1).

The physiological, morphological and biochemical characteristics of strain KMM $6059^{\mathrm{T}}$ were tested as described previously (Nedashkovskaya et al., 2003, 2004); they are given in the species description below and in Table 2 . Similarities in phenotypic characteristics and cellular fatty acid composition support the inclusion of strain KMM $6059^{\mathrm{T}}$ within the genus Mesonia. However, strain KMM $6059^{\mathrm{T}}$ differed from M. algae based on several phenotypic features, including its ability to move by gliding, to grow at $39^{\circ} \mathrm{C}$, to produce acid from D-glucose and D-maltose and to utilize L-arabinose and D-mannose (Table 2). Whereas $M$. algae strains were able to degrade casein and Tween 40, KMM $6059^{\mathrm{T}}$ could not hydrolyse these substrates. Susceptibility to benzylpenicillin, resistance to carbenicillin and oleandomycin and higher $\mathrm{G}+\mathrm{C}$ content of the DNA

Table 1. Fatty acid compositions of Mesonia type strains

Values are percentages of the total fatty acids. Only those accounting for $1.0 \%$ or more in one of the strains are given. - , Not detected.

\begin{tabular}{|lcc|}
\hline Fatty acid & M. mobilis $\mathbf{K M M ~} \mathbf{6 0 5 9}^{\mathbf{T}}$ & M. algae $\mathbf{K M M ~} \mathbf{3 9 0 9}^{\mathbf{T}}$ \\
\hline iso- $_{15: 1}$ & $38 \cdot 3$ & $36 \cdot 7$ \\
anteiso- $\mathrm{C}_{15: 0}$ & $4 \cdot 0$ & $11 \cdot 4$ \\
iso- $_{15: 0}$ & $9 \cdot 7$ & $9 \cdot 8$ \\
$\mathrm{C}_{15: 0}$ & $7 \cdot 6$ & $6 \cdot 0$ \\
$\mathrm{C}_{15: 1} \omega 6$ & $2 \cdot 3$ & $2 \cdot 9$ \\
iso- $\mathrm{C}_{16: 0}$ & $1 \cdot 0$ & $3 \cdot 4$ \\
anteiso- $\mathrm{C}_{16: 1}$ & $0 \cdot 6$ & $1 \cdot 0$ \\
$\mathrm{C}_{16: 0}$ & $2 \cdot 2$ & $0 \cdot 9$ \\
$\mathrm{C}_{16: 1} \omega 7$ & $8 \cdot 1$ & $3 \cdot 6$ \\
iso- $\mathrm{C}_{17: 1}$ & $6 \cdot 2$ & $6 \cdot 5$ \\
$\mathrm{C}_{17: 0}$ & $0 \cdot 4$ & $1 \cdot 0$ \\
$\mathrm{C}_{17: 1} \omega 8$ & $1 \cdot 0$ & $1 \cdot 0$ \\
$\mathrm{C}_{17: 1} \omega 6$ & $2 \cdot 6$ & $1 \cdot 9$ \\
$\mathrm{C}_{18: 1} \omega 7$ & $1 \cdot 0$ & $0 \cdot 5$ \\
iso- $\mathrm{C}_{15: 0} 2-\mathrm{OH}$ & $8 \cdot 3$ & $2 \cdot 9$ \\
iso- $\mathrm{C}_{16: 0} 2-\mathrm{OH}$ & $0 \cdot 7$ & $1 \cdot 0$ \\
iso- $\mathrm{C}_{16: 0} 3-\mathrm{OH}$ & $0 \cdot 5$ & $1 \cdot 4$ \\
iso- $\mathrm{C}_{17: 0} 3-\mathrm{OH}$ & $2 \cdot 3$ & $3 \cdot 7$ \\
anteiso- $\mathrm{C}_{17: 0} 3-\mathrm{OH}$ & - & $1 \cdot 0$ \\
\hline
\end{tabular}


Table 2. Differential phenotypic characteristics of Mesonia species

All strains were positive for the following tests: presence of oxidase, catalase and alkaline phosphatase, $\mathrm{Na}^{+}$requirement for growth, growth with $1-12 \% \mathrm{NaCl}$ and at $4-34{ }^{\circ} \mathrm{C}$, hydrolysis of gelatin and Tween 20, susceptibility to lincomycin and resistance to gentamicin, kanamycin, neomycin, polymyxin B and streptomycin. All of the strains were negative for the following tests: requirement for organic growth factors, $\beta$-galactosidase activity, nitrate reduction, flexirubin pigments, indole and acetoin production, degradation of agar, DNA, starch, cellulose (carboxymethylcellulose and filter paper), chitin and urea, acid production from L-arabinose, D-cellobiose, L-fucose, D-galactose, D-lactose, L-raffinose, D-melibiose, L-rhamnose, sucrose, L-sorbose, adonitol, dulcitol, glycerol, inositol, mannitol, malate, fumarate and citrate and utilization of D-lactose, sucrose, adonitol, dulcitol, inositol, mannitol, sorbitol, malonate and citrate. Data are taken from Nedashkovskaya et al. (2003) (for four strains of M. algae) and this study.

\begin{tabular}{|lcc|}
\hline Characteristic & M. mobilis $\mathbf{K M M ~} \mathbf{6 0 5 9}^{\mathbf{T}}$ & M. algae \\
\hline Gliding motility & + & - \\
Growth at $39^{\circ} \mathrm{C}$ & + & - \\
$\mathrm{H}_{2} \mathrm{~S}$ production & - & + \\
Degradation of casein and Tween 40 & - & + \\
Acid production from D-glucose and D-maltose & + & - \\
Utilization of L-arabinose, D-glucose and D-mannose & + & - \\
Susceptibility to: & & - \\
$\quad$ Benzylpenicillin & - & + \\
Carbenicillin and oleandomycin & $36 \cdot 1$ & $32-34$ \\
DNA G + C content (mol\%) & & \\
\hline
\end{tabular}

may be also used to differentiate the new isolate from M. algae.

Thus, on basis of the phenotypic, genotypic and molecular distinctiveness of strain KMM $6059^{\mathrm{T}}$, we suggest that it represents a novel species in the genus Mesonia, for which the name Mesonia mobilis sp. nov. is proposed.

Although bacteria belonging to the genus Mesonia were described as non-motile organisms, gliding motility was observed for cells of strain KMM $6059^{\mathrm{T}}$. For this reason, and because data on phospholipid composition are now available, we provide an emended description of the genus Mesonia.

\section{Description of Mesonia mobilis sp. nov.}

Mesonia mobilis (mo.bi'lis. L. fem. adj. mobilis movable, mobile, referring to the ability to move by gliding).

Cells are Gram-negative, strictly aerobic with respiratory metabolism, chemo-organotrophic, motile by gliding, asporogenic and rod-shaped, ranging from 0.4 to $0.5 \mu \mathrm{m}$ in width and from $1 \cdot 0$ to $2 \cdot 1 \mu \mathrm{m}$ in length. Oxidase-, catalase- and alkaline phosphatase-positive and $\beta$-galactosidase-negative. Colonies are circular, convex and shiny with entire edges. Colonies are 1-3 $\mathrm{mm}$ in diameter when grown on marine agar. Produces non-diffusible yellow pigments. Flexirubin-type pigments are absent. Grows in the presence of $1-12 \% \mathrm{NaCl}$, at $4-39{ }^{\circ} \mathrm{C}$ and at $\mathrm{pH} 6 \cdot 0-9 \cdot 5$. Optimal growth is observed with $3-4 \% \mathrm{NaCl}$, at $28-30{ }^{\circ} \mathrm{C}$ and at $\mathrm{pH} 7 \cdot 5$. Degrades gelatin and Tween 20 . Does not hydrolyse agar, casein, starch, cellulose (carboxymethylcellulose and filter paper), chitin, DNA, urea or Tweens 40 or 80 . Forms acid from D-glucose and D-maltose, but not from Larabinose, D-cellobiose, L-fucose, D-galactose, D-lactose, D-melibiose, sucrose, L-raffinose, L-rhamnose, L-sorbose, DL-xylose, $\mathrm{N}$-acetylglucosamine, adonitol, dulcitol, glycerol, inositol, mannitol, malate, fumarate or citrate. Nitrate is not reduced. $\mathrm{H}_{2} \mathrm{~S}$, indole and acetoin (Voges-Proskauer reaction) are not produced. Susceptible to ampicillin, benzylpenicillin and lincomycin. Resistant to carbenicillin, gentamicin, kanamycin, neomycin, oleandomycin, polymyxin B, streptomycin and tetracycline. The predominant cellular fatty acids are straight-chain unsaturated, branchedchain unsaturated and saturated, namely iso- $\mathrm{C}_{15: 0}(9 \cdot 7 \%)$, anteiso- $\mathrm{C}_{15: 0}(4 \%), \mathrm{C}_{15: 0}(7 \cdot 6 \%)$, iso- $\mathrm{C}_{15: 1}(38 \cdot 3 \%)$, $\mathrm{C}_{16: 1} \omega 7(8 \cdot 1 \%)$, iso- $\mathrm{C}_{17: 1}(6 \cdot 2 \%)$ and iso- $\mathrm{C}_{15: 0} 2-\mathrm{OH}$ $(8 \cdot 3 \%)$. The $\mathrm{G}+\mathrm{C}$ content of the DNA is $36 \cdot 1 \mathrm{~mol} \%$.

The type strain, KMM $6059^{\mathrm{T}}\left(=\mathrm{KCTC} 12708^{\mathrm{T}}=\mathrm{LMG}\right.$ $23670^{\mathrm{T}}$ ), was isolated from seawater collected in Troitsa Bay, Gulf of Peter the Great, East Sea (also known as the Sea of Japan).

\section{Emended description of the genus Mesonia Nedashkovskaya et al. 2003}

The description is as given by Nedashkovskaya et al. (2003), with the following changes. Cells may be motile by means of gliding. Phosphatidylethanolamine is the only phospholipid identified. The $\mathrm{G}+\mathrm{C}$ content of the DNA is in the range 32-37 mol\%. The type species is Mesonia algae. 


\section{Acknowledgements}

This research was supported by grants from the Russian Foundation for Basic Research (no. 05-04-48211) and the Presidium of the Far Eastern Branch of the Russian Academy of Sciences (no. 06-04-96067) and State Contract 'Collection of Marine Micro-organisms' from the Federal Agency for Science and Innovations of the Russian Federation.

\section{References}

Bernardet, J.-F., Nakagawa, Y. \& Holmes, B. (2002). Proposed minimal standards for describing new taxa of the family Flavobacteriaceae and emended description of the family. Int J Syst Evol Microbiol 52, 1049-1070.

Bligh, E. G. \& Dyer, W. J. (1959). A rapid method of total lipid extraction and purification. Can J Biochem Physiol 37, 911-917.

Christie, W. W. (1982). Lipid Analysis: Isolation, Separation, Identification and Structural Analysis of Lipids. Oxford: Pergamon Press.

Felsenstein, J. (1993). PHYLIP - phylogeny inference package, version 3.5c. Distributed by the author. Department of Genome Sciences, University of Washington, Seattle, USA.

Fitch, W. M. \& Margoliash, E. (1967). Construction of phylogenetic trees: a method based on mutation distances as estimated from cytochrome $c$ sequences is of general applicability. Science 155, 279-284.

Kim, S. B., Falconer, C., Williams, E. \& Goodfellow, M. (1998). Streptomyces thermocarboxydovorans sp. nov. and Streptomyces thermocarboxydus sp. nov., two moderately thermophilic carboxydotrophic species isolated from soil. Int J Syst Bacteriol 48, 59-68.

Kimura, M. (1980). A simple method for estimating evolutionary rates of base substitutions through comparative studies of nucleotide sequences. J Mol Evol 16, 111-120.

Marmur, J. (1961). A procedure for the isolation of deoxyribonucleic acid from microorganisms. J Mol Biol 3, 208-218.

Marmur, J. \& Doty, P. (1962). Determination of the base composition of deoxyribonucleic acid from its thermal denaturation temperature. J Mol Biol 5, 109-118.

Nedashkovskaya, O. I., Kim, S. B., Han, S. K. \& 7 other authors (2003). Mesonia algae gen. nov., sp. nov., a novel marine bacterium of the family Flavobacteriaceae isolated from the green alga Acrosiphonia sonderi (Kütz) Kornm. Int J Syst Evol Microbiol 53, 1967-1971.

Nedashkovskaya, O. I., Kim, S. B., Han, S. K., Rhee, M. S., Lysenko, A. M., Falsen, E., Frolova, G. M., Mikhailov, V. V. \& Bae, K. S. (2004). Ulvibacter litoralis gen. nov., sp. nov., a novel member of the family Flavobacteriaceae isolated from the green alga Ulva fenestrata. Int J Syst Evol Microbiol 54, 119-123.

Saitou, N. \& Nei, M. (1987). The neighbor-joining method: a new method for reconstructing phylogenetic trees. Mol Biol Evol 4, 406-425.

Vaskovsky, V. E. \& Terekhova, T. A. (1979). HPTLC of phospholipid mixtures containing phosphatidylglycerol. J High Resolut Chromatogr Chromatogr Commun 2, 671-672.

Vaskovsky, V. E., Kostetsky, E. Y. \& Vasendin, I. M. (1975). A universal reagent for phospholipid analysis. J Chromatogr 114, 129-141. 